\title{
Solid Waste Management Trends in Nigeria
}

\author{
Ebikapade Amasuomo ${ }^{1} \&$ Jim Baird $^{1}$ \\ ${ }^{1}$ School of Engineering and Built Environment, Glasgow Caledonian University, UK \\ Correspondence: Ebikapade Amasuomo, School of Engineering and Built Environment, Glasgow Caledonian \\ University, Cowcaddens Road, G4 0BA, Glasgow, UK. E-mail: ebiyoko@yahoo.co.uk
}

Received: September 28, 2016 Accepted: October 13, 2016 Online Published: November 25, 2016

doi:10.5539/jms.v6n4p35 URL: http://dx.doi.org/10.5539/jms.v6n4p35

\begin{abstract}
The purpose of this paper is to investigate the current trend of solid waste management in Nigeria and to identify the major challenges inhibiting the attainment of sustainable solid waste management in the country. The study relied on a desktop study approach; hence, data were obtained from previous publications relevant to the current study, particularly from peer reviewed publications. Sources such as waste management agencies websites, reports and documents, journal articles, environmental organizations reports and books were also used to obtain information and data.

It was found that solid waste management is a major concern in the country. Inadequate environmental policies and legislations, low level of environmental awareness, poor funding and inappropriate technology, corruption and unplanned development were some of the challenges facing solid waste management in the country. As a result, the paper concludes that for waste management to work, various aspects of Government services such as engineering, urban planning, Geography, economics, public health and law among others must be brought together under a proper policy to deliver an effective waste management system.
\end{abstract}

Keywords: Nigeria, solid waste management, Port Harcourt, environmental awareness, policies

\section{Brief Description of Nigeria}

Nigeria is one of the Sub Saharan countries located in the western region of Africa. The country operates the federal system of government in which people are governed by three tiers of government. These are the Federal, States and Local Governments (Afon, 2007). The country is diverse, both in its people and landscape. Whilst the southern areas are dotted with beaches, tick vegetation and hills such as the Obudu Hills. Other notable geographical features include the rainforest, the Lagos estuary and savannah in the middle and south west of the country and the Sahel to the encroaching Sahara in the north (Ogwueleka, 2009). The country has a landmass of about one million square kilometres (Nwaka, 2005).

The Atlantic Ocean in the south and the Sahel in the North influences the climatic conditions of the country. Hence, Adejuwon (2006) reported that as one moves from the southernmost part of the country to the northernmost part, a sharp contrast exit in the climatic conditions. He added that about $25 \%$ of the country is humid; these areas are the rainforest zones. About 35\% are semi-arid; these are the Sudan savannah and the Sahel zones. Sub humid zones make up $40 \%$ of the landmass; these areas are the Guinea savannah zones. Olaniran (1991) reported a difference in the rainfall pattern between the south and north. The study found that the moist south-westerly wind from the Atlantic Ocean which brings moisture into Nigeria reduces as it advances northward.

Nigeria is the most populous nation in Africa with about 37 states. The country has an average population growth rate of about $3 \%$. There are currently more than 125 Million people in the country and it is estimated that $50 \%$ of the population lives in cities (Nwaka, 2005).

\section{Introduction}

It is widely accepted that the management of solid waste is a global problem. This problem is even more pronounced in developing countries such as Nigeria where solid waste management is a major concern. Adeyemi et al. (2001) observed that solid waste constitutes a major problem in most developing countries. Adeyemi added that waste management is one of the most intractable problems facing city administrators and environmental agencies. Ogwueleka (2009) reported that solid waste management is by far one of the greatest challenges facing environmental bodies in the country. As a result of the management challenges, Adefemi \& Awokunmi (2009) 
reported a breakdown of law and order in relation to waste management. They observed that urban centres are experiencing an increased rate of environmental deterioration as a result of indiscriminate dumping of solid waste.

Omuta (1987) noted that one notable flaw in waste management administration in developing countries is the unavailability of a proper waste management policy. His view is that for waste management to work, various aspects of Government services such as engineering, urban planning, Geography, economics, public health and law among others must be brought together under a proper policy to deliver an effective waste management system. Ogwueleka (2009) argues that some of the approaches used in tackling the waste problems in Nigeria have recorded very little success. He observed that, the approaches do not distinguish the different needs and diversities of the different cities in the country. He added that these approaches are capital intensive and bureaucratic.

Ezeah \& Roberts (2013) observed that the state of solid waste management in Nigeria has been a major concern to stakeholders. Ogwueleka (2009) reported that inefficient collection and unsafe disposal are some of the characteristics of waste management in the country. Ogu (2000) highlighted that about $80-90 \%$ of wastes generated in some low level income communities in Africa are not collected for safe disposal.

Imam et al. (2009) reported that piles of wastes are dumped by the road side and other open spaces thereby posing environmental risk. It is in response to these flaws that (Imam et al., 2008) submitted that solid waste management has indeed becomes an important issue in Nigeria. Corroborating this view, (Izugbara \& Umoh, 2004) reported that the waste management crisis in the country is already visible. They added that to a large extent, waste management contributes to social, political and environmental costs. These costs are thought to have enormous implications for the economy and the populace (Izugbara \& Umoh, 2004).

Omuta (1987) reported that the major players involved with waste management in Nigeria are the public and the private sector. His view is that, the public sector is driven by the government agencies and the ministry of environments in the various states. He added that some of these governments agencies could be federal, states or local government bodies. On the other hand, Omuta observed that private sector involvement in waste management is driven by private companies. He added that these companies either partners with government agencies or provide waste management services to companies, commercial premises or members of the public for a fee. He noted another form of private initiatives in solid waste management; these are the informal waste collectors which collect waste for a fee. This introduction of private companies in waste management became necessary as a result of the degradation of the environment from inefficient waste management practices (Ogu, 2000).

Ogbonna et al. (2007) reported that in response to the enormous challenges pose by municipal solid waste management, the Government is taking steps to address these problems by engaging local contractors to evacuate waste. Ogu (2000) added that such steps were necessary in order to bring private sector investment into waste management and to enhance service delivery. Ogbonna et al. (2007) observed that cities are divided into sections for the local contractors. However, inefficiency still thrives due to the lack of coordination on the part of the Government and the lack of expertise on waste management issues by the environmental agencies.

The reasons behind inefficient waste management practice in Nigeria have been well researched. For example, Agunwamba (1998) reported that there is a general lackadaisical attitude on the part of the government towards waste management. In addition, Adeyemi et al. (2001) observed that in Nigeria the management of municipal solid waste revolves mainly around open burning, open dumps, landfilling, reuse/recycling and waste conversion. Arukwe (2012) added that the only management practice adopted widely throughout Nigeria involves disposal of waste on open dumps.

\section{Methodology}

The paper reviews wastes management trend in Nigeria with focus on management practices in major cities across the country and the general challenges faced by waste management agencies in Nigeria. The paper relied on secondary data as the sole source of information for the research, with emphasis on peer reviewed journals and governments reports. This desktop approach was chosen over other research methodologies such as mix method and quantitative research methods. The desk study approach was found to be more suitable for the present paper due to the fact that this approach deals primarily with the collection of information from existing research. On the other hand, quantitative approach is suitable for research dealing with numerical data while the mix method approach deals with studies utilizing both numerical and qualitative data. The approach used in the current paper was found to be sufficient in attaining the objectives of the study. 


\section{Discussion}

Waste management practises across Nigeria remain poor. Researchers have reported a similar pattern of management at states and city levels. There are about 37 states in Nigeria including the Federal Capital Territory; most of these states are faced with similar challenges. This section of the paper briefly examines the wastes management trends prevalent in some major cities across Nigeria.

\subsection{Management Trends across Nigerian Cities}

\subsubsection{Ibadan City, Oyo State}

Adeoye et al. (2005) reported the existence of illegal solid waste dumps in several parts of the city. He found that these waste dumps undergo physical and chemical changes under the intense heat of the sun thereby posing the risk of pollution to the ecosystem. A study of market waste in Ibadan (Bammeke \& Sridhar, 1989) shows that the environmental conditions in most of the city markets are poor. Their study stated that, while waste is continuously being generated, arrangements are not made for their effective collection, transportation and disposal. Ayininuola \& Muibi (2008) pointed out that heaps of solid wastes including abandoned vehicles are common in some parts of Ibadan.

Ibadan is the capital city of Oyo state. A survey of 648 household in the city (Afon \& Okewole, 2007) reveals that the per capital solid waste generation is estimated to be $0.129 \mathrm{~kg}$ per day. The survey revealed that about $75.4 \%$ of the total wastes generated are organic materials. They pointed out that there are potentials for reuse and recycling through composting or anaerobic digestion of waste produced in the state. Similarly, Bammeke \& Sridhar (1989) noted that about $68 \%$ of market wastes are putrescible. They suggested composting as the best form of treatment.

Similarly, Rahji \& Oloruntoba, (2009) noted that most waste materials generated in Ibadan especially household waste are mainly made up of food waste. They advised that it is important that the waste should be disposed of using the best means possible as they may constitute environmental hazard during decomposition. Rahji \& Oloruntoba pointed out that a good disposal practice will avoid the creation of a breeding ground for flies, vermin and ground or surface water pollution through leaching and flooding. However, findings from (Ayininuola \& Muibi, 2008) reveal that the collection system in some parts of the city is grossly inadequate as only a fraction of the wastes generated are collected and only a fraction of the collected waste are properly disposed of. They pointed out that changes in the day to day activities in some parts of the city, especially in demographic expansion have led to an increase in the volume and diversity of solid waste. Bammeke \& Sridhar (1989) cited unplanned development as a major cause of the current waste management practice in the city. They went on to say that one other major cause of indiscriminate dumping in the city is the inability of the authorities to provide effective waste management service.

\subsubsection{Port Harcourt}

Ayotamuno \& Gobo (2004) reported that a time was when the city of Port Harcourt was referred to as the garden city of Nigeria. This was due to its cleanliness and beautiful vegetation. These days, however, refuse from various sources forms litter in various parts of the city. Igoni et al. (2007) indicated that although large quantities of the refuse generated in Port Harcourt are collected, some are left to form litters in some parts of the city.

Ogbonna et al. (2007) added that householders deposit their waste at designated collection centres which are usually located along major roads and public markets. These wastes are then collected by the local contractors working in partnership with government agencies. Despite this arrangement, Ayotamuno \& Gobo (2004) reported that indiscriminate dumping still persists in the city. Other disposal methods such as burying and open burning are also used (Igoni et al., 2007).

Ogbonna et al. (2007) noted that the old Port Harcourt Township once had a good level of infrastructure with good drainage system and waste disposal centres. However, the rapid population growth that accompanied the discovery of oil and the lack of government control on new development gave rise to housing shortages and unplanned road network in the city. Ogbonna and others believe that this pattern of informal development make effective waste management a difficult task. Omuta (1987) suggests that uncontrolled development and poor urban structure can poses a big constrains on solid waste management as they create difficulty and accessibility problems.

\subsubsection{Lagos}

An examination of the current solid waste management in Lagos reveals a similar trend to other cities of Nigeria. However, some improvements have been made in the city. Ezeah \& Roberts (2013) noted that Lagos state has made some significant progress in growing institutional capacity for solid waste management. Solomon (2009) 
observed that Lagos is one of the few states in Nigeria that provide collection service from house to house and communal collection points. He reported that the state commissioned a transfer loading system, to serve several areas of the state. The project will see waste being compacted before transferring them to dump sites. However, Adewole (2009) reveals that there are several areas that still need to be improved upon, if the objectives of sustainable developments must be achieved. He pointed out that most of the industries around the Isolo area of Lagos still do not have pollution abatements programmes in place. Hence, the Lagos lagoon absorbs 10,000 m3 of industrial effluent daily.

Despite attempts to organise a collection system in Lagos, Kofoworola (2007) argues that there are still inadequate facilities for waste management in the state. He found that, some inhabitants of the state use illegal disposal route such as dumping along the streets and motor ways. A study (Afon, 2007) of two local governments in Lagos state reveals that residents store waste in small containers. Some of the containers include plastic and metal unused buckets, bowls, polythene and nylon bags. The study pointed out that the use of such small storage containers helps residents' to get a good bargain by paying less to informal waste collectors for the disposal of their waste. He added that this storage system attracts disease carrying vectors such as flies and rats.

Kofoworola (2007) observed that Lagos does not have an integrated approach to waste management and the problems associated with the current system of management are obvious. Afon (2007) reveals that dumping of waste into the drainage channels and in public places are common practices among residents. Currently no treatment exists for collected wastes, which are transported to landfill sites and burnt for volume reduction. Kofoworola (2007) added that this burning process releases harmful gases to the ecosystem. Hence, Longe et al. (2009) advised that a management approach that emphasizes waste reduction, recycling and reuse should be adopted.

Another major problem with waste management in Lagos is that wastes are not separated. A study (Ogundiran \& Afolabi, 2008) of leachate characteristics in a Lagos landfill reveals that industrial and household waste is dumped together at the Olusosun landfill. This is particularly hazardous to the environment as the wastes are dumped on the landfill without treatment. Adewole (2009) argues that since most landfills in Lagos are not engineered, leachate will percolate into streams and ground water sources. He also suggests that an approach with an organised system of collection from industrial and domestic sources should be adopted. Solomon (2009) suggested that there is a need for landfills in Nigerian cities to be built to the required standard.

However, Solomon (2009) observed that some progresses are being made in terms of solid waste in Lagos. He stated that, since a large percentage of solid waste generated in Lagos is putrescible, a private company recently established a composting plant capable of treating 1500 tons of solid waste per day. In addition to this, Ezeah \& Roberts (2013) stated that the Lagos state agency responsible for waste management was recognised for its effort by the Federal ministry of commerce and industry in 2010. They added that other organisations such as United Nation Development Program, Clinton Foundation and USAID have recognised the effort of the body through awards or sponsorships. However, they noted that there are still some governance issues in the state as regards waste management.

\subsection{Challenges of Solid Waste Managements in Nigeria}

Various studies (Agunwamba, 1998; Omuta, 1987; Ayotamuno \& Gobo, 2004; Ogu, 2000; Babayemi \&Dauda, 2009; Ogwueleka, 2009; Ezeah \& Roberts, 2012; Taiwo, 2011; Izugbara \& Umoh, 2004; Ayininuola \& Muibi, 2008) have highlighted several factors as the challenges facing solid waste management in different cities across Nigeria. Some of these factors are discussed below;

\subsubsection{Inadequate Environmental Policies and Legislation}

Agunwamba (1998) pointed out that there is a loop hole in the government policies on solid waste management. He observed that, although the public are urged to partake in the monthly exercise to clean up the city, the efforts of the residence have not been complemented through the provision of disposal sites. This problem persists throughout the country. For example, Nzeadibe \& Anyadike (2012) reported that no articulate piece of legislation deals with solid waste management in the city of Aba. They argued that due to weak institutional framework and enforcement of policies Solid waste management is not considered a priority by the state government (Ayotamuno \& Gobo, 2004). Ezeah \& Robert (2012) noted that the legal framework on waste management is weak. Their view is that the waste policies in place do not have strategies for realisation. Hence, they suggested a review of the legislative aspects of solid waste management in other to work towards achieving the objectives of waste hierarchy. In addition, they suggested a management approach which should incorporate re-use and recycling, composting and energy generation and waste prevention.

In some instances where good policies are in place, their implementation remains a problem. For example, 
environmental impact assessments are meant to be tendered during the planning of a project before they can be approved. However, this regulation is often ignored (Agunwamba, 1998). Adewole (2009) criticised the enforcement and implementation of environmental laws in Nigeria. He argues that, generally the enforcement of environmental laws in the country has been a source of concern. He added that the management and regulation of environmental laws have had very little success. His view is that some of the enforcement problems in Nigeria have political, social and economic undertones. Similarly, Imam et al. (2008) argues that for there to be sustainability in waste management, proper policy and planning in addition to an aggressive enforcement of waste management legislation must be implemented.

A study conducted on solid waste management in Port Harcourt (Ayotamuno \& Gobo, 2004) indicated that even where policies are in place, they are not clear enough, hence, they are open to different interpretation. They pointed out that the National environmental law is not clear enough on the authority responsible for collection and disposal of waste in the various states. Several academic papers agree with this submission as a close study on cases studies across the country reveals a confusing picture. For instance, Solomon (2009) revealed that Lagos state government is responsible for solid waste management while Abel (2007) observed that solid waste management in Ogbomosho town is handled by the Local Government Council.

This ambiguity is also reported in (Adeyemi et al., 2001) in a study which suggested that it is the responsibility of the Municipal Council or the State Environmental Protection Agencies to collect waste for disposal in the states. This confusion in who should manage waste has led to an overlap of function among the waste management bodies in the country, thus creating problems for effective waste management.

Ayotamuno \& Gobo (2004) noted that, in industrialised countries, the main role of the state government in waste management is to control the management system, while the waste management service is left to the local government. They cited the mode of operation in Britain where residence pays a monthly fee to the council to enable good service delivery. However in Nigeria, Omuta (1987) reported an inability of the municipal government to perform this duty effectively.

Another major barrier in terms of solid waste management policies and legislation is the lack of continuity and implementation of government policies. To this end, laws should be developed and implemented to reduce at source (Kofoworola, 2007; Solomon, 2009). Similarly, Ezeah \& Roberts (2013) reported that political interference in Abuja results in instability in waste governance and lack of continuity in policies. They argue that policies are often set aside due to changes in administration of waste management bodies.

It is therefore clear that the current policies and waste management legislations in place are not sustainable. Hence, Adewole (2009) in order to achieve a successful waste management, laws must be formulated to rid the system of ambiguity and avoid overlap of environmental laws.

\subsubsection{Low Level of Environmental Awareness and Enlightened Public}

One of the most important factors in solid waste management is the cooperation of the public. In Nigeria the level of environmental awareness is low. Rahji \& Oloruntoba (2009) argue that there is a need for government to engage in environmental campaign in order to enlighten the public on best environmental practice. Rahji \& Oloruntoba (2009) suggested that increasing the awareness of the people may have a positive impact on their attitude towards the environment. Imam et al. (2008) pointed out that there is a wide spread lack of environmental awareness and concern on environmental issues. Nabegu (2010) observed that, in Kano, wastes were dumped indiscriminately on the streets and in public places and water bodies. His study shows that householders are only interested in their immediate vicinity. Only $11 \%$ of the people interviewed as part of the study express concern for environmentally sound and safe waste disposal.

Imam et al. (2008) concluded that the level of awareness and the attitude of the people can greatly affect solid waste management process. They observed that the level of awareness can impact on domestic waste storage, segregation, littering and fly tipping, recycling, collection frequency among others. Furthermore, Nabegu (2010) pointed out that the level of environmental awareness will influence the effectiveness and sustainability of municipal waste management system. Furthermore, Omuta (1987) in his study of Benin explains that improvements can be observed if the public is carried along during the planning and implementation of solid waste management programs. He suggests that community leaders should be engaged in the policy making process. He reckons that successful integration of the people may improve cooperation.

Adewole (2009) reported that the negative waste disposal habit of most people in Lagos is fuelled by ignorance and poverty. He added that the manner in which people discharge garbage into drains or highways seems to suggest that Nigerians are permanently accustomed to dirt. Kofoworola (2007) suggested that government should use all media resources available to them to enlighten the people on the need to dispose their wastes at 
designated drop off points. He pointed out that indiscriminate dumping should be penalised. Omuta (1987) added that educational programs should be aimed at developing skills for the prevention of environmental degradation. He added that school curricula should also ensure proper environmental habits.

However, Nabegu (2010) argues that it is not enough to enlighten the public; his view is that efforts to build awareness should be backed up by improvement in waste collection services. In addition, Agunwamba (2003) commented that enlightenment programs should be sensitive to the particular needs and the socio economic needs of the people. He suggests that programs should be geared towards encouraging a reuse and recycle. He added that the impact of not recycling on the environment, economy and health should be explained properly.

\subsubsection{Poor Funding}

To a large extent inadequate funding has been identified by several researchers as one of the most predominant factor affecting solid waste management in Nigeria, (Agunwamba, 2003; Ayotamuno \& Gobo, 2004; Ezeah \& Roberts, 2012; Izugbara \& Umoh, 2004; Ogu, 2000; Ogwueleka, 2009). It has been suggested that the financial strength of environmental agencies in the country has not been able to parallel the rate at which solid waste is being generated. Ogwueleka (2009) argues that environmental agencies do not have the capacity to perform their duties effectively due to limited budgets. He suggested that the low morale among waste management agencies personnel resulting from poor remuneration, affect solid waste management. In Port Harcourt for instance, like most states in the country, the state government is the sole financier of solid waste management (Ayotamuno \& Gobo, 2004). They argued that this system of funding is not sustainable. Hence, Imam et al. (2008) suggested that some form of user charge might help reduce the burden of funding on the government.

A study of waste management in Benin (Ogu, 2000), Nigeria showed that waste management is capital intensive. The study added that despite the financial implication of waste management, there was no concrete plan being made for the recovery of some of the cost from residence. This was attributed to the fact that people are not used to paying for municipal waste management. Furthermore, Omuta (1987) explains that as much as $30 \%$ of the locally generated revenue by the Benin local council is spent on solid waste management. He suggested that at least $5 \%$ of the country's revenue should be earmarked for solid waste management. In addition, he advised that a fee should be charged for the service. However, such fees should take the low level of income into consideration.

Similarly, Afon \& Okewole (2007) noted that solid waste management is not regarded as important in the scheme of things by the three tiers of government in the country. Hence, there are some occasional long periods of financial neglect of the solid waste management agencies. Moreover, Ezeah \& Roberts (2013) argues that since waste management agencies are not involved in budgetary allocations. Waste management departments are overlooked and underfunded. Hence, it is difficult them to employ and retain experts in waste management. Ezeah \& Roberts (2013) pointed out that as a result of shortage of funds waste management agencies are unable to purchase equipments needed for efficient service delivery.

Agunwamba (1998) noted that the low level of funding seriously hinders the operations of the waste management agencies. He commented that collection operations are sometimes cancelled or delayed due to lack of fuel for collection vehicles. Furthermore, Ezeah \& Roberts (2013) criticised the poor funding of waste management bodies. They observed that shortage of funds often leads the agencies to purchase old/used machineries from Europe. Agunwamba (1998) advised that in other to improve on solid waste management, adequate funding arrangement should be put in place. He suggested that this should be done through private initiative and cooperation with the private sector. In addition to this, he suggested that funding should also be provided for waste management research.

\subsubsection{Inappropriate Technology and Inadequate Facilities}

From the literature it is clear that, in Nigeria, local conditions are not taken into consideration before the adoption of a waste management strategy. Ogwueleka (2009) revealed that irrespective of the local conditions most cities in Nigeria adopt open dumping or uncontrolled landfills as their disposal route. This may be attributed to the fact that in most cases state environmental bodies are headed by politicians and their associates. The management system in place is usually haphazard since the people in charge have very little or no training on solid waste management. A good example of this, was illustrated by a study (Leton \& Omotosho, 2004) which found that, although the principle of landfilling is widely used in most open dumps across Nigerian cities, the geologic assessment conducted in the course of the study revealed that open dumps and landfilling are not suitable for some states in The Niger Delta. This is particularly true in Bayelsa state due to the fact that the area is overwhelmed with water. That is, highly waterlogged all year round. The same study suggested that Yenagoa and Bayelsa state as a whole should adopt alternative disposal or treatment method rather than landfill. 
The challenges faced by solid waste management agencies in Nigeria differs significantly from those in most industrialised nations mainly in terms of the waste composition, volume of waste, the economic conditions, area of collection coverage, density and politics. Solid wastes in Nigeria are more corrosive, weighty and are saturated with water than those in industrialised nations (Ogwueleka, 2009). Hence, a different solid waste management approach is required. For example, Imam et al. (2008) argues that since the waste composition in Abuja shows that a large percentage of the waste generated are organic in nature, compaction trucks may not be appropriate. Yet about half of the collection vehicles owned by the state solid waste management agency are compaction trucks. Furthermore, Nabegu, (2010) reveals that the compaction trucks used in developed countries achieve just a little compression rate in Nigeria, due to the high density of solid waste. The study further revealed that compactor trucks will not be effective in some Nigerian cities.

Agunwamba (1998) pointed out that some of the solid waste treatment facilities in the country are not suitable to local conditions. He argued that some of the machines employed in waste management do not have local spare parts. Similarly, Ezeah \& Roberts (2012) observed that some of the old solid waste collection vehicles brought into the country from developed countries are quickly abandoned due to unavailability of spare parts. Agunwamba (1998) concluded that equipment that cannot be serviced or maintained locally will amount to a waste of resources in the long term.

Solomon (2009) observed that the incineration plants in Lagos are not currently operational. Ogwueleka (2009) suggest that incineration plants are an expensive waste management technology. His view is that their operation requires a proper disposal for their residual ash and an efficient monitoring of gaseous emission. Solomon (2009) added that incineration of waste will achieve a better result in countries with less that $20 \%$ water content in their waste. He observed that the water contents of solid waste in Lagos are about $30-40 \%$ liquid. Hence, these incinerators were never used. Some of them were decommissioned while one was converted to a recreational facility. Hence, it is fairly obvious that incineration plants for Nigerian cities as the heavy moisture contents in the waste will make combustion difficult (Ogwueleka, 2009).

Ogwueleka (2009) suggested that in other to achieve a sustainable level of solid waste management, institutional, political, social, financial, economic and technical aspect of solid waste management should be studied.

\subsubsection{Politics and Corruption}

It has been observed (Ezeah \& Roberts, 2013) that the political class regularly interfere with solid waste management in Abuja, particularly in the area of appointments of managers to waste management agencies. Similarly, Agunwamba (1998) observed that the belief that officials tasked with enforcing environmental laws can always be bribed prevent people from taking environmental laws seriously.

Agunwamba (1998) noted that politics rather than environmental considerations influence the location of waste management facilities. He argued that this system often leads to illogical and wasteful decisions. Adewole (2009) also argued that the inability of previous Lagos state waste management authority to deliver a sustainable waste management service may be due to corruption. He stated that waste management officials are known to have demanded money before collecting waste from markets. He added that, in some other cases, informal waste operators have been asked for bribes before they can dispose of their waste on the dump sites thus leading to illegal dumping. Agunwamba (1998) also added that personal interests have often led to delays or stoppage of environmental policies in the country.

\subsubsection{Unplanned Developments and Population Increase}

This is perhaps one of the greatest challenges facing solid waste management in the country. Ogbazi, (2013) concluded that urban planning have failed in Nigeria due to several factors such as weak policies and laws, designs that are similar and based on foreign cultures. Hence, Agunwamba (1998) concluded that this lack of planning and adequate development makes solid waste collection a difficult task. He observed that they lead to settlements without street planning and accessible roads. Nwaka (2005) criticises the government role in the rapid expansion of unplanned settlements. He argues that overregulation on the part of the government in allocating cheap land to prospective developers give rise to illegal settlements. Nweke observed that only about $20-40 \%$ of developments have government approvals. He went on to add that although there is a law on urban and regional planning, efforts have not been made to implement the law by the government agencies responsible for the implementation.

The finding of a survey in Kano (Nabegu, 2010) reveals that about 69\% of respondents believes that only a small fraction of the state has access to waste collection service. The survey noted that this is mainly due to the inaccessibility of most parts of the city. Nwaka (2005) reveals that this haphazard planning by the government result in the type of development observed in Kano where residential areas are inaccessible to waste 
management agencies. He added that the increase in informal settlements is mainly due to the fact that the informal sector has been at the forefront of urban housing. Similarly, Ayotamuno \& Gobo (2004) pointed out that as the neighbouring villages around Port Harcourt began to develop with little or no government approval and planning. Urban planning with good road network was not put into consideration.

Ogbazi (2013) stated that most government bodies on urban planning have approached planning development haphazardly. In the long term, this lack of planning impacts negatively on solid waste management. Nwaka (2005) observes that in Nigeria, the drainage systems have open drains, in form of a trenches with little width and depth. These drainages are usually blocked with industrial and domestic materials and other rubbish carried by flood water. Nwaka noted that environmental awareness is still at the elementary level especially among the informal settlers.

Imam et al. (2008) pointed out that, in some cases where there are roads in Abuja for instance, heavy traffic often impedes the collection process. The waste management agency tried a system whereby wastes are collected at night. However, it was found to be problematic due to security concerns. Agunwamba (1998) noted that one of the consequences of irregular planning of developments is the long hauling time of solid waste due to heavy traffic conditions. He noted that this has the potential to reduce effective waste management.

The difficulties of coping with the rapid urbanization have completely overwhelmed African cities, Nigeria inclusive (Ogbazi, 2013). Rapid population growth and urbanisation have been closely linked with unplanned development and informal settlements. Ogbonna (2007) suggested that after hydrocarbons were found in the city, Port Harcourt began to witness a boom in population which quickly led to uncontrolled development and inaccessible settlements. Similarly, it was noted that the problems of solid waste management in Nigeria have been exacerbated by increased urbanization and population growth. This is because they not only increase the volume of waste generated, they also increase the challenge of effective supervision of waste management program (Agunwamba, 1998; Ayotamuno \& Gobo, 2004).

In addition, Sangodoyin (1993) argues that rapid urbanization also increases the difficulty of getting the vast land needed for the siting on of a landfill to accommodate the increasing waste arisings. Afon \& Okewole (2007) pointed out that as the growth in population continues more land will be needed to cater for the extra waste that will be generated. He argues that Oyo Township will need an additional 1.3 acres of land annually to accommodate the projected annual growth rate of $3 \%$. He noted that about 39.5 acres of land was acquired to cater for the waste arisings of the 394,632 inhabitants of the town in 2005. He therefore projected that in the next 20-30 years an additional 26.9-48.7 acres will be needed for the dumping of waste in the town going by the annual population growth.

Ogbonna et al. (2007) noted that the population of an area is a major factor that determines the volume of waste generation in the area. He added that there was an increase of about $25.4 \%$ in the volume of waste generated in Port Harcourt between 2000 and 2001. He concluded that solid waste management agencies should adopt an approach which charges residents according to the volume of waste they generate. He suggested that such an approach will enforce a healthy environment.

\section{Conclusion}

Waste management across Nigeria have deteriorated significantly over time, without a doubt the management approaches employed in tackling waste management challenges have recorded very little success. Hence, only a handful of cities such as Lagos seem to be making significant progress in addressing the wastes management challenges inherent in their localities. The reason for this failure is that the approaches do not distinguish the different needs and diversities of cities across the country. In addition, the lack of coordination and expertise on waste management issues by the environmental agencies and other organs of Government promotes inefficiency.

It is clear from the paper that the bulk of the problems relating to waste management in the country is as a result of the unavailability of proper waste management policy. Therefore in order to achieve sustainability in the sector, various aspects of Government services such as: engineering, urban planning, Geography, economics, public health and law among others must be brought together under a proper policy to deliver an effective waste management system. The development of a clear policies as well as adequate enforcement is likely to serve as a major driver towards sustainability in waste management.

\section{References}

Adefemi, S. O., \& Awokunmi, E. E. (2009). The impact of municipal solid waste disposal in Ado Ekiti metropolis, Ekiti State, Nigeria. African Journal of Environmental Science \& Technology, 3, 186-189. 
Adejuwon, J. O. (2006). Food crop production in Nigeria. II. Potential effects of climate change [WWW Document]. Retrieved from http://www.int-res.com/articles/cr2006/32/c032p229.pdf

Adeoye, G. O., Sridhar, M. K. C., Adeoluwa, O. O., \& Akinsoji, N. A. (2005). Evaluation of naturally decomposed solid wastes from municipal dump sites for their manurial value in southwest Nigeria. J.

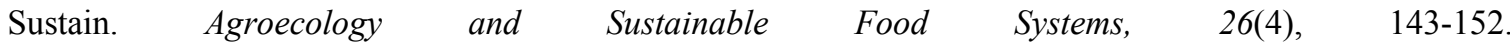
https:/doi.org/10.1300/j064v26n04_09

Adewole, A. T. (2009). Waste management towards sustainable development in Nigeria: A case study of Lagos state. International Ngo Journal, 4, 173-179.

Adeyemi, A. S., Olorunfemi, J. F., \& Adewoye, T. O. (2001). Waste scavenging in Third World cities: A case study in Ilorin, Nigeria. Environmentalist, 21(2), 93-96. https://doi.org/10.1023/A:1010655623324

Afon, A. O. (2007). Informal sector initiative in the primary sub-system of urban solid waste management in Lagos, Nigeria. Habitat International, 31(2), 193-204. https://doi.org/10.1016/j.habitatint.2007.02.007

Afon, A. O., \& Okewole, A. (2007). Estimating the quantity of solid waste generation in Oyo, Nigeria. Waste Management \& Research the Journal of the International Solid Wastes \& Public Cleansing Association Iswa, 25(4), 371-379.

Agunwamba, J. C. (1998). Solid waste management in Nigeria: problems and issues. Environmental Management, 22(6), 849-856. https://doi.org/10.1007/s002679900152

Ayininuola, G. M., \& Muibi, M. A. (2008). An engineering approach to solid waste collection system: Ibadan North as case study. Waste Management, 28(9), 1681-1687. https://doi.org/10.1016/j.wasman.2007.06.004

Ayotamuno, J. M., \& Gobo, A. E. (2004). Municipal solid waste management in Port Harcourt, Nigeria: Obstacles and prospects. Management of Environmental Quality, 15(4), 389-398. https://doi.org/10.1108/14777830410540135

Bammeke, A. O., \& Sridhar, M. K. C. (1989). Market Wastes in Ibadan, Nigeria. Waste Management \& Research, 7(2), 115-120. https://doi.org/10.1016/0734-242X(89)90056-6

Ezeah, C., \& Roberts, C. L. (2014). Waste governance agenda in Nigerian cities: A comparative analysis. Habitat International, 41(1), 121-128. https://doi.org/10.1016/j.habitatint.2013.07.007

Igoni, A. H., Ayotamuno, M. J., Ogaji, S. O. T., \& Probert, S. D. (2007). Municipal solid-waste in Port Harcourt, Nigeria. Applied Energy, 84(6), 664-670. https://doi.org/10.1016/j.apenergy.2006.12.002

Imam, A., Mohammed, B., Wilson, D. C., \& Cheeseman, C. R. (2008). Solid waste management in Abuja, Nigeria. Waste Management, 28(2), 468-472. https://doi.org/10.1016/j.wasman.2007.01.006

Izugbara, C. O., \& Umoh, J. O. (2004). Indigenous waste management practices among the Ngwa of southeastern Nigeria: some lessons and policy implications. Environment Systems and Decisions, 24(2), 87-92. https://doi.org/10.1007/s10669-004-4799-4

Kofoworola, O. F. (2007). Recovery and recycling practices in municipal solid waste management in Lagos, Nigeria. Waste Management, 27(9), 1139-1143. https://doi.org/10.1016/j.wasman.2006.05.006

Leton, T., \& Omotosho, O. (2004). Landfill operations in the Niger delta region of Nigeria. Engineering Geology, 73(1), 171-177. https://doi.org/10.1016/j.enggeo.2003.12.006

Longe, E., Longe, O., \& Ukpebor, E. (2009). PEOPLE'S PERCEPTION ON HOUSEHOLD SOLID WASTE MANAGEMENT IN OJO LOCAL GOVERNMENT AREA, IN NIGERIA. Iranian Journal of Environmental Health Science \& Engineering, 6, 209-216.

Nabegu, A. B. (2010). An analysis of municipal solid waste in Kano Metropolis, Nigeria. Journal Hum. Ecol. 31(2), 111-119.

Nwaka, G. I. (2005). TREATING PEOPLE AND COMMUNITIES AS ASSETS.

Nzeadibe, T. C., \& Anyadike, R. N. C. (2012). Social participation in city governance and urban livelihoods: Constraints to the informal recycling economy in Aba, Nigeria. City Culture \& Society, 3(4), 313-325. https://doi.org/10.1016/j.ccs.2012.10.001

Ogbazi, J. U. (2013). Alternative planning approaches and the sustainable cities programme in Nigeria. Habitat International, 40(3), 109-118. https://doi.org/10.1016/j.habitatint.2013.03.001 
Ogbonna, D. N., Amangabara, G. T., \& Ekere, T. O. (2007). Urban solid waste generation in Port Harcourt metropolis and its implications for waste management. Management of Environmental Quality, 18(1), 71-88. https://doi.org/10.1108/14777830710717730

Ogu, V. I. (2000). Private sector participation and municipal waste management in Benin City, Nigeria. Environment and Urbanization, 16(2), 103-117. https://doi.org/10.1177/095624780001200209

Ogundiran, O. O., \& Afolabi, T. A. (2008). Assessment of the physicochemical parameters and heavy metals toxicity of leachates from municipal solid waste open dumpsite. International Journal of Environmental Science and Technology, 5(2), 243-250. https://doi.org/10.1007/BF03326018

Ogwueleka, T. (2009). Municipal solid waste characteristics and management in Nigeria. Iranian Journal of Environmental Health Science \& Engineering, 6(3), 173-180.

Olaniran, O. J. (1991). Evidence of climatic change in Nigeria based on annual series of rainfall of different daily amounts, 1919-1985. Climatic Change, 19(3), 319-340. https://doi.org/10.1007/BF00140169

Omuta, G. E. D. (1987). Urban solid waste generation and management in Nigeria: Towards an environmental sanitation policy. Habitat International, 11(2), 77-87. https://doi.org/10.1016/0197-3975(87)90058-0

Rahji, M. A. Y., \& Oloruntoba, E. O. (2009). Determinants of households' willingness-to-pay for private solid waste management services in Ibadan, Nigeria. Waste Management \& Research the Journal of the International Solid Wastes \& Public Cleansing Association Iswa, 27(10), 961-965. https://doi.org/10.1177/0734242X09103824

Sangodoyin, A. Y. (1993). Considerations on contamination of groundwater by waste disposal systems in Nigeria. Environmental Technology, 14(10), 957-964. https://doi.org/10.1080/09593339309385370

Solomon, U. U. (2009). The state of solid waste management in Nigeria. Waste Management, 29(10), $2787-2788$. https://doi.org/10.1016/j.wasman.2009.06.030

\section{Copyrights}

Copyright for this article is retained by the author(s), with first publication rights granted to the journal.

This is an open-access article distributed under the terms and conditions of the Creative Commons Attribution license (http://creativecommons.org/licenses/by/4.0/). 